\title{
Job Satisfaction as an Agent of Development of the People Who Work at the University of La Guajira (Colombia)
}

\author{
Elvis Eliana Pinto Aragon ${ }^{1 *}$, Carmenza Leonor Mendoza Catano ${ }^{1}$, Annherys Isabel Paz Marcano ${ }^{2}$ \\ and Geomar Molina-Bolivar ${ }^{3}$ \\ 'Grupo de Investigacion Encuentro Con La Investigacion, Universidad de La Guajira, Colombia; epinto@uniguajira. \\ edu.co,cmendoza@uniguajira.edu.co \\ ${ }^{2}$ Grupo de Investigacion AIKA, Universidad de La Guajira, Colombia; aipaz@uniguajira.edu.co \\ ${ }^{3}$ Grupo de Investigacion BIEMARC, Universidad de La Guajira, Colombia
}

\begin{abstract}
Objective: This research was aimed to analyze the job satisfaction as an agent of development of the people in the University of La Guajira. Materials and Methods: The positivist paradigm of descriptive and analytical research, non-experimental design, transactional in the field, the information was applied the technique of the survey and instrument a questionnaire of 24 items with multiple options to 59 employees of the administrative career, validated by 5 experts while reliability is Cronbach's Alpha applied the formula with 0.91 of reliability and interpreted the data using descriptive statistics. Findings: Job satisfaction is based on extrinsic factors, as an agent of development in the university object of study, creating an area that provides synergy, conviviality and well-being to the collaborators through the achievements awarded as opportunity for professional growth and development in the area of work that serves as the tool associated to gain knowledge and skills, thus developing attitudes for the benefit of the work in their day-to-day work during the performance of assigned functions. Application/Improvements: It is suggested to keep the factor of satisfaction in the work spaces, managing to increase motivation in the work performance of the staff of the administrative career.
\end{abstract}

Keywords: Extrinsic Factors, Job Satisfaction, Personal Development, Quality of Working Life, University of La Guajira

\section{Introduction}

The complexity of the contemporary world, has created an environment of uncertainty in the work scenarios that transcends in the management of organizations, without exclusion of the universities, where the changes and transformations of the intoned they have led to efforts for the establishment of criteria that provide answers to the needs of work spaces, without putting at risk the satisfaction of the people involved, as development factors that contribute to the well-being, quality of life, motivation and performance ${ }^{1}$. In such a way that the universities as institutions are called to fulfill its role from academic, research and extension. These makes them carriers of the development agents and achieve excellence in the performance of the processes at work, through the indicators that give answers to the activities described in the institutional plans that have inserted the social projection one of their missionary principles in the formation of human talent.

The social dynamics that has been done in recent years in university education, has led to focus its activities not only in teaching, research and extension, but have focused their role in complying with its commitments to its people, and the environment. It is as well as the universities as an agent of formation of persons should be included in

${ }^{*}$ Author for correspondence 
the development plans of activities that contribute to the well-being and job performance of its employees, considering their attitudes, skills and knowledge to get results with excellence in missionary activities ${ }^{2}$. Therefore, job satisfaction, is a topic of interest in the management of persons in institutions. In the University of La Guajira external factors of the reference medium ensure stability, it is associated with conditions such as hours, communication, remuneration, working environment, benefits and services obtained, possibilities of college career, human relations; that together represent indicators that contribute to the satisfaction, motivation and job performance of workers and their expectations in the work environment.

Several studies have developed about the people who work in the universities, but few know about external factors associated with satisfaction in the workplace. Since job satisfaction, becomes the nutrient that feeds people, reflected in the performance of their role as worker. Job satisfaction and organizational commitment are constructs that are of interest to psychologists and in particular for those dedicated to the area of Human Resources $^{3}$. For this reason, this research inquired both constructs and their relationship in the employees of a private university in the year 2011. The scale of job satisfaction SL-SPC and the scale of the degree of commitment of the ASD to University employees 121 people belonging to a population of 300 individuals in status of employees ${ }^{1}$. The results of the research revealed that there is job dissatisfaction in a $51.3 \%$, being the dimensions conditions/materials and administrative policies with which employees feel more dissatisfied; however, despite the previous result, 91\% presents high levels of organizational commitment, by what they feel identified with the institution and give their loyalty. The Pearson correlation for the variables of the study of 0.73 , which is statistically significant $(\mathrm{p}=0.10)$ in the studied population. The results of the research revealed that there is job dissatisfaction in a $51.3 \%$, being the dimensions conditions/materials and administrative policies with which employees feel more dissatisfied; however, despite the previous result, 91\% presents high levels of organizational commitment, by what they feel identified with the institution and give their loyalty. The Pearson correlation for the variables of the study of 0.73 , which is statistically significant $(\mathrm{p}=0.10)$ in the studied population.

This research contributes to the study developed at the University of La Guajira (Colombia), bearing in mind that the talent facilitates the attainment of the objectives referred to in the institutional plans and how social cell contributes to job satisfaction as an agent of development of the people, allowing to analyze the external factors that determine a rewarding and motivating for the exercise of the work of the partners, leading to the achievement of the goals, both personal and institutional arrangements; in addition to generate a satisfactory performance in favor of obtaining positive results in the institutional management. Therefore, as an institution at the service of society, must move in trends that facilitate look opportunities, promoting actions that will integrate the university management toward models of work that are conducive to the satisfaction of the people toward the development of the co-workers, and may employ human management strategic plans which expresses the need to achieve job satisfaction in mind and as the improvement of the institutional competitiveness.

There are a number of theories that have been used to the satisfaction of the people in the areas of work, with a focus on the results to achieve the desired productivity in economic terms for its stability in the market, leaving in the background the satisfaction of this in the environment, where it exercises its functions. It is in this way, how can you make mention of Herzberg's theory or two factors; the first factor is identified as intrinsic or motivating, includes the job-employee relationship, achievement, recognition, promotion, the challenging work and responsibility, and the second factor is the extrinsic; aggregates policies, management of the company, interpersonal relations, salary, supervision and working conditions $s^{4}$.

In this sense, it explains that the aforementioned theory has been the basic source, to study the satisfaction of the people in their areas of work, where by way of interest in this investigation, is based on precepts, to know the reality perceived by the staff of the administrative career at the University of La Guajira, where not only translates into being, but as well in the work place satisfaction. The job satisfaction includes the perception gained from the co-workers in the performance of their work, which becomes a means to achieve their purposes not only personal but also professional, where the results can be positive or negative, it is combining both in feelings and emotions. In such a way, that is a conceptual framework for understanding the various authors, in terms of job satisfaction. That is to say, it is the attitude to work, highlighting discrepancies about conception associated with the assigned job function versus the results that demand performance, why is often perceived in a positive or nega- 
tive. The conceptualization of job satisfaction has been described by various authors $\frac{5,6}{}$.

According to the consulted academic positions, job satisfaction takes place in the interior of the people who manifest in their behavior; that is when the person feels effective or not with the result of your performance. In addition, external factors generated by interactions in the space of labor and the working environment ${ }^{5}$. The conditions surrounding the individual when you work highlights the physical and work environments. In such a way that, a work emblematic in the administration is to contribute to the work of the man at work, as it is specified via the intrinsic characteristics associated with the operational context of the desempenocomo: opportunity, opportunity to control the use of externally generated goals, skills, environmental variety and clarity ${ }^{4}$. In the same vein, between the extrinsic features of the job are immersed in tasks and activities rather than on their content, others, such as: availability of money, physical security, opportunity of interpersonal contacts and social position valued. Therefore, the dimension that examines the components or indicators associated to the satisfaction of the person on the opportunities and development in the organization, system of awards, achievements, job characteristics, mechanisms for monitoring, system or policies of wages and salaries, interpersonal relations and policies of the company. Possibility of growth which has an individual to achieve promotion of their work environment and the recognition referred to in the thanks expressed by the administration before a job well done ${ }^{5.7}$.

On the other hand the recognition, as a tool associated with the personal needs as the ego or self-esteem, that every individual internalized are a reward for achieving stand out socially ${ }^{8}$. In addition, self-fulfillment and self-respect; this is the contribution expressed by managers to collaborators, at the time of observing the results achieved in the performance of the tasks assigned to it, that is highlighting its competencies to jobs well done. The Achievement are the results obtained by the effort made in the organization. This is the wish that I feel a person to achieve clear objectives, self-determined and moderately complex, with feedback, based on the achievement of the objectives self-certain 1 . For its part, the characteristics of the work refers to the satisfaction of the employee in relation to the nature of the work and monitoring is the process by which establishes the control of the organization. In this regard, they argue that the role of the supervisor in the institution is of vital importance, where everything that is done depends mainly on the, to be responsible for the unit. However, the supervisor serves as a link or link and influences their staff encouraging, promoting good relations and to serve as a paradigm to all its employees?.

On the other hand, the wage is a motivator, governs the life pattern of each individual in the social context, in function of their work ${ }^{10}$. For organizations, labor represents a cost, at the same time an investment, then refers to cost because the salary refers to the cost of the final product or service and investment, representing the money applied to a productive factor (work) in an attempt to achieve greater performance in the short or medium term. The structures of wages must be equi and just in relation to other posts with the organization that seeks to find the internal balance in wages and salaries when they relate to similar positions in other companies active in the labor market, this external balance for the amount of money that the agreed in the contract of employment and that normally paid to the worker ${ }^{10,11}$.

Colombian law does not embody the meaning of salary, however, if referred to in article 23 of the Labor Code, as one of the elements of the contract of employment ${ }^{12}$. Article 14 of the Law 50 of 1990 claims that it constitutes wages not only the regular, fixed or variable, but that which receives the worker in money or in kind as direct consideration by the service, whatever the shape or name given to it: premiums, bonuses, bonuses, value of the additional work or overtime, value of work in mandatory days of rest, percentages on sales and commissions ${ }^{12,13}$. In the end, the extrinsic factors of job satisfaction in the context of the University of La Guajira, is associated with the monetary compensation, generated from the treatment of wages for employees of the administrative career attached to it, which is conditioned by various factors such as: opportunity and development, recognition, achievements, characteristics of the work, supervision, wages and salaries, interpersonal relations and policies of the company.

\section{Materials and Methods}

This research corresponds to the positivist paradigm, with the purpose to analyze the job satisfaction as an agent of development of the people in the University of La Guajira, being the objects of study to know the characteristics relating to facts inserts in the variable, which can improve the well-being of the collaborators, in addition 
to meet your needs. The applied research for the generation of knowledge with direct application to the problems of society or the productive sector, which is based on the findings of basic research, to pursue the process of link between the theory and the product ${ }^{14}$. In this regard, the research includes a study applied, in order to pretend to respond to a situation that might affect the institutional management at the University of la Guajira, through the quality of working life that offers as part of its commitment in relation to satisfy the needs of the employees of the administrative career.

Table 1. Population distribution of the respondents of the study at the University of La Guajira

\begin{tabular}{|l|l|}
\hline Charges & NumberofCollaborators \\
\hline Professional & 28 \\
\hline Technical & 15 \\
\hline Auxilliary & 16 \\
\hline Total 59 & \\
\hline
\end{tabular}

According to the level of research is characterized as descriptive, because it goes beyond the exploration. In addition, it seeks to specify the properties, characteristics and profiles of individuals, groups, communities or any other phenomenon that is submitted to an analysis, descriptive research asserts characteristic aspects, where different aspects are identified, components and their interrelationships, having as its purpose the delimita-

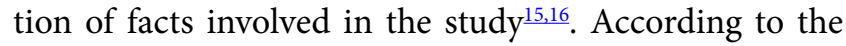
approach can be inferred to be compiled data that subscribe facts characteristic related to the variable of study, as a dimension of the quality of working life in administrative career employees of the University of La Guajira (Colombia). Therefore, the objectives of the study seek to analyze the extrinsic factors of the quality of working life of the administrative career employees who work at the University of La Guajira. In the same way, is a analytical research, due to the fact that reinterprets the results according to certain criteria, dependent on the objectives in study ${ }^{15}$.

In the same way, it is considered field, where the collection of information was obtained on the site of occurrence of the facts achieving results that led to the systematic analysis of the problem with the purpose to describe it, explain its causes, effects, and extend its nature, as well as the constituent factors that allow to predict its occurrence, being in this particular administrative areas of the University of La Guajira ${ }^{11}$. Losestudios de campo, recogen los datos directamente de la realidad ${ }^{17}$. Eldiseno de la investigacion viene a constituir el plan o estrategia que se concibe para alcanzar los objetivos planteados en el estudio, conllevando sus acciones a dar respuestas a los interrogantes presentados en el mismo, asi como analizar la certeza de las posturas planteadas en un contexto particular ${ }^{15}$.

Taking into account the above definitions, the present study is located in the non-experimental designs, it is not the intention of the researchers deliberately manipulate the variables, but observe the behavior of the phenomenon as given in its natural context, for them to interpret the data. In this order of ideas, it is proposed that in nonexperimental research studies are carried out without the deliberate manipulation of variables, and in those who are only observed the phenomena in their natural environment for later analysis ${ }^{15}$. The type of non-experimental research design, is set out in the cross-sectional descriptive category, obtaining information on the variable studied at a unique moment selected by the researchers, and then perform the analysis and interpretation. Experimental designs do not cross-sectional study to collect data in a single moment, in one moment in time, with the purpose to describe variables and analyze its effects and interaction at a given time $\frac{15}{}$.

For the population, taking into accounts that they... "It is the set of all elements to which it refers the investigation"(8). In the same way, it was based on the concept that "population is the set of all cases that meet certain specifications, on the basis of content characteristics, of the time and place"15. In this sense, according to the conceptual source, it was established that the study population, understood to reporting units, made up of 59 people, whose characteristics are finite and accessible, which is why there was a calculation of the sample but a population census. In the census of the population take the whole unit which is made up of the population, as can be seen in Table $1 \frac{8,18}{\text {. }}$.

The technique used in the collection of data was the observation by means of a survey, which is an observation instrument formed by a series of questions whose answers are recorded by the interviewer, this allows the knowledge of the motivations, attitudes and opinions of individuals in relation to its object of research ${ }^{16}$. In the case of the registration of the information was used a questionnaire, containing a set of items related to the object of study, having multiple alternative response mode. A questionnaire 
is an instrument of data collection structured by a set of reagents which are intended to evaluate the indicators arising from the operationalization of the research ${ }^{15,19}$. In this case, the questionnaire asked about the extrinsic factors of job satisfaction in the university object of study, was formed by 24 reagents prepared in the form of statements with multiple options of response of always, almost always, sometimes, almost never, and never.

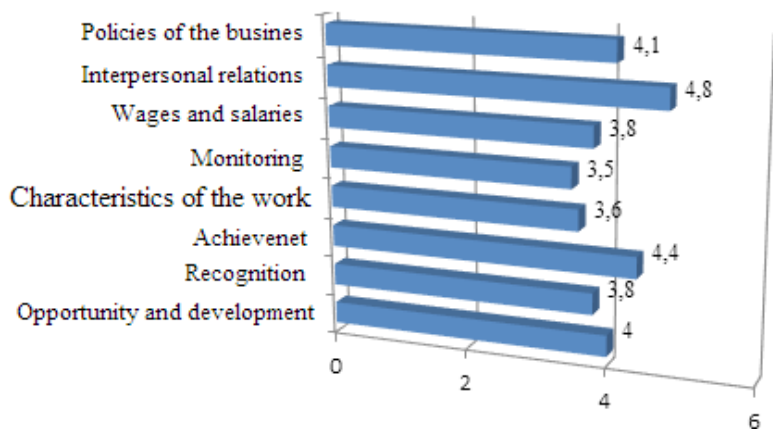

Figure 1. Distribution of frequencies on the behavior of variables such as extrinsic factors of job satisfaction in the University of La Guajira.

To generate the effectiveness of data collection instrument, recourse was hard to the consultation of 10 experts in the fields of human talent management and research methodology, which issued its opinion about the relevance of the same with the object of study ${ }^{15}$. Define the validity as the degree where an instrument measures the variable that seeks to measure. After we know the relevance of the instrument designed to measure the behavior of the variable in the stage of study, conducted a pilot study with 10 subjects of institutions with similar characteristics to the population, in order to calculate the reliability. The reliability of an instrument is the degree to which an instrument produces results consistent and coherent, that is to say that your repeated application to the same individual or object produces the same results, ranging between 0 and 1 , therefore, the authors infer that an instrument of measurement can be reliable, but not necessarily valid, however, it must be demonstrated that this meets both requirements ${ }^{15}$. Therefore, for the calculation of the reliability, is required for the election of the statistical method, this will depend both on the nature of the study and the choices of answers contain in the questionnaire items, selecting for this purpose for the present investigation the Cronbach's Alpha equation listed below ${ }^{20}$ :
$r=\frac{K}{K-1}\left[\frac{1-\sum S_{i}^{2}}{S_{t}^{2}}\right]=\frac{66}{66-1}\left[\frac{1-56,98^{2}}{535,35^{2}}\right]=0,907$

Where:

R: Result of the Cronbach's Alpha coefficient.

$\mathrm{K}$ : Number of items of the questionnaire.

$S^{2} \mathrm{i}$ : Variance of the scores of each item.

$S^{2} t$ : Variance of the total scores.

1: Numeric constant value

After replacing the elements in the equation, for the calculation, the result was a reliability index of 0,91 represented in percentages with a $91 \%$ reliability. The statistical techniques used to analyze and interpret the information collected from the instrument, being the most handled the distribution of frequency, and as measures of central tendency the arithmetic mean, geometric, medina and fashion; while in the measures of dispersion the variance, standard deviation, coefficient of variation $\frac{16,21}{}$.

Table 2. Baremo scale of interpretation of the levels of job satisfaction

\begin{tabular}{|l|l|}
\hline Ranges & Categories \\
\hline $1,00 \geq 2,60$ & Low \\
\hline $2,61 \geq 3,40$ & Media \\
\hline $3,41 \geq 5,00$ & High \\
\hline
\end{tabular}

In relation to the analysis and interpretation of the results expressed by the opinion of the population surveyed, we used the Excel $^{\circ}$ spreadsheet where was quantified, organized, registration, and tabulated the data, allowing to analyze the results. Prior to this, the encoding, by assigning a numerical factor to the responses to the questionnaire, where the numerical expression of the multiple answers was: Always (5), almost always (4), (3), (2) almost never, never (1). The encoding to the data means assigning a numeric value or symbol to represent them, being necessary to assign them quantitatively ${ }^{15}$. According to the Criteria tab, the management of the information was processed and quantified by items and grouped by variables ${ }^{16}$. The organizations of the choices of answers were recorded in matrices, with the purpose to apply statistical methods of descriptive statistics: absolute and relative frequency of information and interpreted through a Baremoscale ${ }^{15}$. 


\section{Results and Discussion}

The analysis of the results was carried out by applying descriptive statistics, with the support of interpretation of absolute and relative frequencies to determine the behavior of the variable factors extrinsic job satisfaction, taking as a context for study at the University of La Guajira, to reason to consider the opinion of the administrative career employees seconded to it. In this regard, we calculated the mean values of the dimensions, indicators and items. The results were analyzed using a scale of interpretation of average values. In addition, the frequency distribution of allowed to know the level percentage from the opinion of the respondents (Table 2). In this sense, the calculation of the frequency of the variable data, are presented and illustrated in Figure 1.

In which corresponds to the extrinsic factors of job satisfaction, in the Table 3 shows the data of the indicator opportunity and development, in which the 43.25 per cent of the employees in the administrative career stated that the university always gives opportunity for professional growth in their area of work; a $27.12 \% 16.95 \%$, almost always argues that sometimes and in a lower percentage 3.39\% said they almost never the university gives the opportunity for professional growth. On the other hand, 50.42 Add\% believes that there are always plans for promotion at the university; $18.64 \%$ of the respondents indicated that almost always, a $15,25 \%$ of the same report that at times, and the lowest percentage value was awarded to a 3.39 per cent are opposed to almost never there are plans for promotion at the university. Therefore, the $49.15 \%$ raised that sometimes receive training when there is the opportunity to occupy a higher level; $20.34 \%$ feel that always, the $16.95 \%$ almost never, in both the $13.56 \%$ stated that almost always receive training in the case of the opportunity to occupy a higher level in the institution.

At the prompt recognition, $47.46 \%$ of the respondents reveal that always recognized the performance of their work; a $35.59 \%$ in the same way that almost always takes place such recognition and the remainder with an $8.47 \%$ of employees claim that sometimes. Within this context, the $49.15 \%$ of the respondents said written almost always receive recognition for their superior performance to the desired, a $42.37 \%$ indicates that as long as the $8.47 \%$ of them feel that sometimes receive the recognition for their performance. In relation to the $55.93 \%$ reflects that sometimes expressed dissatisfaction with the immediate boss when others give recognition where he participated; a $16.95 \% 13.56 \%$, never answered almost never and a $10.17 \%$ expressed their discontent with the situation, and the remaining $3.39 \%$ indicate almost never. With regard to the indicator achievement, the $45.76 \%$ of the respondents are of the opinion that the head sometimes feeds on indicators achieved in their performance; a $28.81 \%$ almost always, a $25.42 \%$ manifest always receive feedback from your immediate boss of indicators achieved as a result of their performance in the institution.

Within this framework, the $81.36 \%$ of the employees in the administrative career that is always encourages the continuous improvement of the work to achieve the excellence of the dependency on the part of the immediate boss, $11.86 \%$ indicate that almost always, the remaining $6.78 \%$ reveal that sometimes the head immediately stimulates the improvement of the work continued to achieve together the excellence. For its part, the $69.49 \%$ of the staff of the administrative career noted that always propose corrective measures to detect failures to achieve institutional goals, a $20.34 \%$ say almost always and the remaining $10.17 \%$ enunciated sometimes proposed corrective measures to detect failures to achieve institutional goals. In Table 3 about the extrinsic factors dimension of quality of life in the workplace, the characteristics of the work, the $61.02 \%$ believe that always performs assigned work even if it is not what you expect to do; a $16.95 \%$ almost always performs assigned work even if it is not what you expect to do, $15.25 \%$ of them performs assigned work even if it is not what you expect to do, the remaining $6.78 \%$ indicates almost never performed the work assigned even if this is not what you expect to do.

According to Table 3, the $42.37 \%$ of the respondents expressed satisfaction with the development of their immediate boss the work assignment; $23.73 \%$ of them are of the opinion almost always, the $18.64 \%$ reveal some times and a $15.25 \%$ indicate that almost never express the satisfaction of the work assigned to your immediate boss. On the other hand, $33.90 \%$ of the surveyed employees sometimes rejects the development of a job when you do not know how to construct it; $30.51 \%$ indicate that almost never, a $15.25 \%$ manifest almost always and equal percentage value is $15.25 \%$ never generates rejection to this situation. In the Indicator Monitoring at Work $50.85 \%$ of the respondents show that the immediate boss always encourages the management of its work, $27.12 \%$ 


\begin{tabular}{|c|c|c|c|c|c|c|c|c|c|c|c|c|c|c|c|c|c|c|c|c|c|c|c|c|c|}
\hline \multirow{3}{*}{ 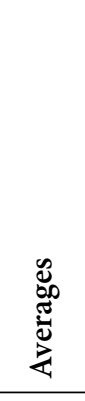 } & 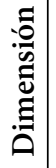 & \multicolumn{9}{|c|}{$\stackrel{\circ}{f}$} & & & & & & & & & & & & & & & \\
\hline & $\vec{\Xi}$ & \multicolumn{3}{|c|}{$\stackrel{\circ}{+}$} & \multicolumn{3}{|c|}{$\stackrel{\infty}{\infty}$} & \multicolumn{3}{|c|}{$\stackrel{+}{+}$} & \multicolumn{3}{|c|}{$\stackrel{\vec{n}}{\dot{n}}$} & \multicolumn{3}{|c|}{$\stackrel{n}{n}$} & \multicolumn{3}{|c|}{$\stackrel{\infty}{\infty}$} & \multicolumn{3}{|c|}{$\stackrel{\infty}{+}$} & \multicolumn{3}{|c|}{$\vec{f}$} \\
\hline &. & సे & $\begin{array}{l}\stackrel{H}{*} \\
\stackrel{+}{*}\end{array}$ & $\begin{array}{c}\hat{m} \\
\hat{m}\end{array}$ & $\vec{m}$ & $\stackrel{+}{\stackrel{m}{*}}$ & $\begin{array}{c}0 \\
\hat{v} \\
\hat{v}\end{array}$ & $\begin{array}{l}\infty \\
\infty \\
m\end{array}$ & $\begin{array}{l}\stackrel{2}{n} \\
\underset{f}{f}\end{array}$ & ڤે & $\begin{array}{c}\tilde{\sigma} \\
\stackrel{+}{*}\end{array}$ & $\begin{array}{l}\hat{m} \\
\hat{m}\end{array}$ & 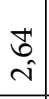 & $\begin{array}{l}\tilde{\rho} \\
\hat{*}\end{array}$ & $\begin{array}{l}\hat{2} \\
\hat{\sim}\end{array}$ & $\begin{array}{l}0 \\
\infty \\
\hat{n}\end{array}$ & 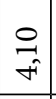 & $\begin{array}{l}n \\
0 \\
+\end{array}$ & त) & 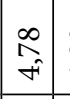 & $\begin{array}{l}\infty \\
\infty \\
+\end{array}$ & \begin{tabular}{l}
0 \\
\multirow{+}{*}{}
\end{tabular} & $\underset{f}{\mathbb{F}}$ & $\begin{array}{l}\stackrel{+}{*} \\
\stackrel{F}{*}\end{array}$ & $\begin{array}{l}\hat{b} \\
\dot{n}\end{array}$ \\
\hline & 厗 & $\begin{array}{l}0 \\
8 \\
0 \\
0\end{array}$ & $\begin{array}{c}\stackrel{0}{0} \\
\hat{\sigma} \\
-1\end{array}$ & $\begin{array}{l}0 \\
8 \\
0 \\
0 \\
0\end{array}$ & $\begin{array}{l}0 \\
\delta^{\circ} \\
0 \\
0\end{array}$ & $\begin{array}{l}\text { oें } \\
\text { ठे } \\
0\end{array}$ & $\begin{array}{c}\stackrel{0}{0} \\
\hat{2} \\
6 \\
-1\end{array}$ & $\begin{array}{l}0 \\
8 \\
0 \\
0\end{array}$ & $\mid \begin{array}{l}0 \\
0 \\
0 \\
0\end{array}$ & $\begin{array}{l}0 \\
\dot{0}^{\prime} \\
0\end{array}$ & $\begin{array}{l}0 \\
8 \\
0 \\
0\end{array}$ & $\begin{array}{l}0 \\
8 \\
0 \\
0\end{array}$ & $\begin{array}{l}\stackrel{0}{10} \\
\stackrel{1}{n} \\
\stackrel{n}{n}\end{array}$ & $\begin{array}{l}\text { oे } \\
\text { mे } \\
\text { mे }\end{array}$ & $\begin{array}{l}\infty \\
\infty \\
\infty \\
\infty \hat{0} \\
\sim\end{array}$ & $\begin{array}{l}\circ \\
8 \\
0 \\
0\end{array}$ & $\begin{array}{l}0 \\
\dot{0} \\
0 \\
0\end{array}$ & $\begin{array}{l}0 \\
\delta^{\circ} \\
0\end{array}$ & $\begin{array}{l}\stackrel{0}{\circ} \\
\stackrel{1}{0} \\
0\end{array}$ & $\mid$ & $\begin{array}{l}0 \\
0 \\
0 \\
0\end{array}$ & $\mid \begin{array}{l}0 \\
8 \\
0 \\
0\end{array}$ & $\begin{array}{l}0 \\
\delta^{\circ} \\
0\end{array}$ & $\begin{array}{l}0 \\
0^{\circ} \\
0 \\
0\end{array}$ & $\stackrel{\circ}{0}$ \\
\hline zे & 洁 & 0 & -1 & 0 & 0 & 0 & & 0 & 0 & 0 & 0 & 0 & $a$ & $\sim$ & $\triangleq$ & 0 & 0 & 0 & 0 & 0 & 0 & 0 & 0 & 0 & - \\
\hline 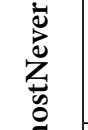 & 常 & $\begin{array}{l}0 \\
\text { के } \\
\text { mे }\end{array}$ & $\begin{array}{l}\infty \\
\infty \\
\hat{0} \\
\hat{0}\end{array}$ & $\begin{array}{l}\stackrel{0}{10} \\
\hat{\alpha} \\
0 \\
-1\end{array}$ & $\begin{array}{l}0 \\
0^{\circ} \\
0 \\
0\end{array}$ & 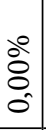 & 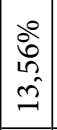 & $\begin{array}{l}0 \\
\delta^{\circ} \\
0 \\
0\end{array}$ & \begin{tabular}{|l|} 
\\
\\
0 \\
0 \\
0
\end{tabular} & $\begin{array}{l}0 \\
8 \\
0 \\
0 \\
0\end{array}$ & $\begin{array}{l}\stackrel{0}{\infty} \\
\stackrel{0}{1} \\
0\end{array}$ & 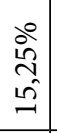 & $\begin{array}{l}\stackrel{0}{a} \\
\vec{n} \\
0 \\
0 \\
\dot{m}\end{array}$ & $\begin{array}{c}0 \\
0 \\
0 \\
\text { in }\end{array}$ & $\begin{array}{l}\stackrel{0}{m} \\
\stackrel{\sim}{n} \\
\hat{\sim}\end{array}$ & 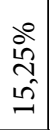 & $\begin{array}{c}0 \\
0 \\
0 \\
0 \\
i n\end{array}$ & 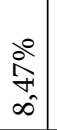 & 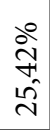 & $\mid$\begin{tabular}{l|}
8 \\
8 \\
0 \\
0 \\
0
\end{tabular} & 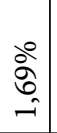 & $\begin{array}{l}0 \\
8 \\
0 \\
0\end{array}$ & $\begin{array}{l}0 \\
0^{\circ} \\
0 \\
0\end{array}$ & $\begin{array}{l}\dot{a}^{\circ} \\
\dot{0} \\
-1\end{array}$ & $\begin{array}{l}\stackrel{0}{0} \\
0 \\
\text { in }\end{array}$ \\
\hline$\frac{E}{4}$ & 政 & $\sim$ & $H$ & 이 & 0 & 0 & $\infty$ & 0 & 0 & 0 & + & $a$ & $\stackrel{\infty}{-}$ & $m$ & $\exists$ & $a$ & $m$ & in & $\stackrel{10}{-1}$ & 0 & -1 & 0 & 0 & - & $m$ \\
\hline$\stackrel{\mathscr{\sharp}}{\Xi}$ & 产 & 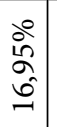 & 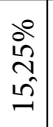 & 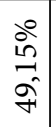 & $\begin{array}{l}\stackrel{0}{0} \\
2 \\
\hat{\sigma} \\
- \\
-1\end{array}$ & 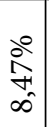 & 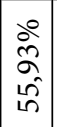 & $\begin{array}{l}\stackrel{0}{0} \\
\stackrel{0}{0} \\
\stackrel{5}{f}\end{array}$ & $\mid \begin{array}{l}0 \\
2 \\
0 \\
0 \\
0\end{array}$ & $\begin{array}{l}\stackrel{0}{1} \\
\stackrel{0}{0} \\
0\end{array}$ & 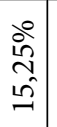 & 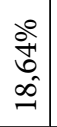 & 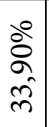 & 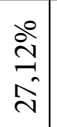 & $\begin{array}{l}\stackrel{0}{\infty} \\
\stackrel{\sim}{\sim} \\
\sim\end{array}$ & $\begin{array}{l}\stackrel{0}{0} \\
\text { - } \\
\infty \\
-1\end{array}$ & $\begin{array}{c}0 \\
\hat{\tilde{o}} \\
\hat{i} \\
\hat{i}\end{array}$ & 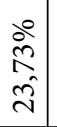 & 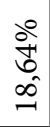 & $\begin{array}{l}0 \\
0 \\
0 \\
10 \\
10\end{array}$ & 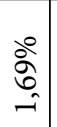 & $\mid \begin{array}{c}2 \\
\hat{2} \\
\hat{m} \\
m^{2}\end{array}$ & 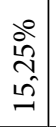 & 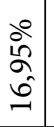 & $\begin{array}{l}\stackrel{0}{\circ} \\
\hat{O} \\
\dot{f} \\
\dot{f}\end{array}$ \\
\hline हैं & 政 & 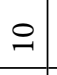 & $a$ & ৯े & 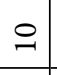 & in & $m$ & $\hat{\sim}$ & + & 0 & $a$ & $=$ & 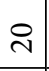 & $\stackrel{0}{0}$ & $\Xi$ & $\exists$ & $\cong$ & $\Xi$ & $\exists$ & $m$ & -1 & $N$ & $a$ & $\circ$ & $\stackrel{\sim}{\circ}$ \\
\hline 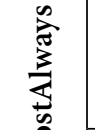 & 产 & 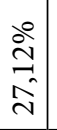 & $\begin{array}{l}\stackrel{0}{0} \\
\stackrel{4}{0} \\
\infty^{0} \\
\rightarrow\end{array}$ & $\begin{array}{l}\dot{0} \\
\dot{0} \\
\hat{\omega} \\
\end{array}$ & 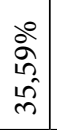 & 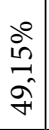 & $\mid \begin{array}{c}2 \\
\hat{2} \\
m \\
m\end{array}$ & $\begin{array}{l}0^{0} \\
\infty \\
\infty \\
\infty^{0}\end{array}$ & $\mid \begin{array}{l}0 \\
0 \\
\infty \\
= \\
=\end{array}$ & 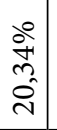 & 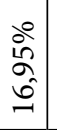 & 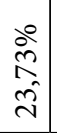 & $\begin{array}{l}\stackrel{0}{0} \\
\stackrel{2}{n} \\
\stackrel{n}{n}\end{array}$ & $\begin{array}{l}\stackrel{0}{0} \\
\stackrel{0}{n} \\
\stackrel{n}{n}\end{array}$ & $\mid \begin{array}{l}\infty \\
\infty \\
\stackrel{0}{0} \\
\hat{\sigma}\end{array}$ & 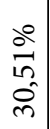 & 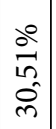 & $\begin{array}{l}0 \\
\hat{0} \\
\hat{\tilde{d}} \\
\hat{v}\end{array}$ & $\begin{array}{l}20 \\
\dot{0} \\
1 \\
n \\
n \\
-\end{array}$ & $\begin{array}{l}0 \\
0 \\
\infty \\
0 \\
= \\
=\end{array}$ & $\begin{array}{c}\stackrel{0}{\circ} \\
\stackrel{+}{\infty} \\
\infty\end{array}$ & $\mid \begin{array}{c}0 \\
\vdots \\
\hat{2} \\
6 \\
-1\end{array}$ & 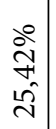 & 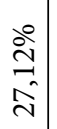 & $\underset{\stackrel{\circ}{\sim}}{\stackrel{\sim}{\sim}}$ \\
\hline 严 & 活 & $\stackrel{0}{\sim}$ & $\exists$ & $\infty$ & $\vec{\sim}$ & શે & $N$ & $\therefore$ & $\wedge$ & $\simeq$ & 이 & \pm & $a$ & $\infty$ & $r$ & $\stackrel{\infty}{-}$ & $\stackrel{\infty}{-}$ & 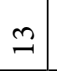 & $\infty$ & 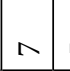 & in & 이 & $\stackrel{2}{2}$ & 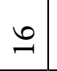 & 0 \\
\hline$\approx$ & 产 & 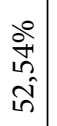 & $\begin{array}{l}\stackrel{0}{0} \\
\hat{b} \\
\hat{n} \\
\text { in }\end{array}$ & 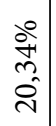 & \begin{tabular}{l}
$\stackrel{0}{0}$ \\
$\dot{t}$ \\
\multirow{f}{f}{} \\
$\hat{f}$
\end{tabular} & 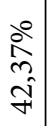 & $\mid \begin{array}{c}\stackrel{0}{1} \\
\stackrel{0}{0} \\
0\end{array}$ & 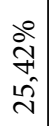 & $\mid$\begin{tabular}{c|}
0 \\
$\dot{0}$ \\
$\stackrel{2}{2}$ \\
$\infty$
\end{tabular} & $\begin{array}{l}\stackrel{0}{\circ} \\
\hat{\sigma} \\
\hat{\sigma}\end{array}$ & $\begin{array}{c}\stackrel{0}{0} \\
0 \\
\overrightarrow{0}\end{array}$ & $\begin{array}{l}\stackrel{\circ}{2} \\
\hat{2} \\
\stackrel{f}{f}\end{array}$ & $\begin{array}{l}00 \\
\infty \\
0 \\
\hat{n}^{n}\end{array}$ & 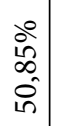 & $\begin{array}{c}20 \\
2 \\
\alpha \\
\sigma \\
0 \\
-1\end{array}$ & $\begin{array}{l}\circ 0 \\
\Delta \hat{n} \\
\hat{n} \\
\hat{n}\end{array}$ & 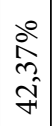 & 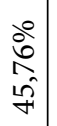 & $\begin{array}{l}\stackrel{0}{0} \\
\stackrel{1}{1} \\
\hat{n} \\
m\end{array}$ & $\begin{array}{c}0 \\
0 \\
2 \\
\hat{0} \\
\infty \\
\infty\end{array}$ & $\begin{array}{c}\stackrel{0}{\partial} \\
\underset{\infty}{0} \\
\infty \\
\infty\end{array}$ & $\mid \begin{array}{l}0 \\
80 \\
0 \\
2 \\
2\end{array}$ & $\begin{array}{l}\text { ஸे } \\
\text { సे } \\
\text { مิ }\end{array}$ & $\begin{array}{l}\stackrel{\circ}{+} \\
\stackrel{+}{+} \\
\stackrel{+}{n}\end{array}$ & $\begin{array}{l}\text { Oे } \\
\hat{0} \\
\hat{i}\end{array}$ \\
\hline$\frac{3}{4}$ & 路 & $\vec{m}$ & mे & $\simeq$ & $\stackrel{\infty}{\sim}$ & $\stackrel{2}{\sim}$ & 0 & $\stackrel{2}{\sim}$ & \begin{tabular}{|l|}
$\infty$ \\
$+\infty$
\end{tabular} & $F$ & i & $\stackrel{2}{\sim}$ & $n$ & $\stackrel{m}{ }$ & 이 & $\vec{\sim}$ & $\stackrel{\sim}{\sim}$ & $\widehat{\curvearrowright}$ & 9 & F & $\approx$ & F & $\stackrel{m}{m}$ & $\approx$ & $\cong$ \\
\hline 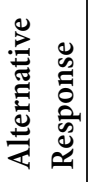 & 节 & $\neg$ & $\sim$ & $m$ & $H$ & in & 0 & $\wedge$ & $\infty$ & $a$ & 이 & $\Rightarrow$ & $\simeq$ & $\ddot{\sim}$ & $\mathbb{J}$ & 10 & 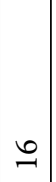 & $\triangle$ & $\stackrel{\infty}{-}$ & 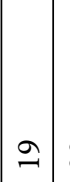 & ஜ & $\vec{\sim}$ & $\approx$ & $\approx$ & $\underset{\sim}{\sim}$ \\
\hline 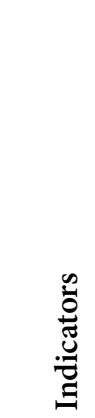 & & & 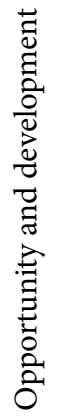 & & & 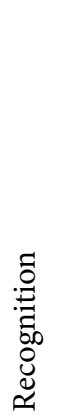 & & & 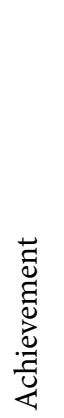 & & & 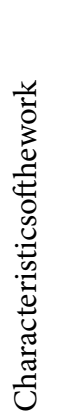 & & & 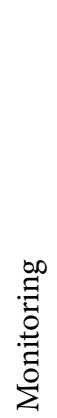 & & & 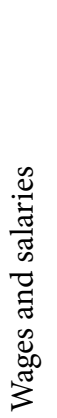 & & & 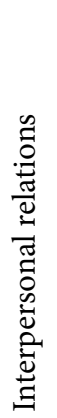 & & & 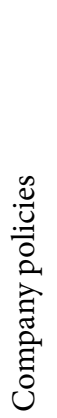 & \\
\hline
\end{tabular}


of them are always, $13.56 \%$ of the opinion almost always, a $5.08 \%$ of them think almost never and the remaining $3.39 \%$ reveal never the head immediately stimulates the management of its work.

Within this context, it is assumed with a 28.81 per cent of the employees in the administrative career that never establishes controls to address the immediate boss in case of doubts in the labor management, a $23.73 \%$ manifest, as well as sometimes a $23.73 \%$ almost never and a $16.95 \%$ stated that as long as the remaining percentage value reflected in a $6.78 \%$ believe that almost always establishes controls to address the immediate boss in case of doubts in the labor management. In reference to the $35.59 \%$ of the respondents show that the immediate boss always monitors the performance of its activities to assess compliance; a $30.51 \%$ say that almost always; a $18.64 \%$ believe that sometimes and the remainder with a $15.25 \%$ almost never develop monitoring by the immediate supervisor in the performance of their activities to assess compliance. In relation to the salaries and wages, the $42.37 \%$ salary expectations for their performance; $30.51 \%$ indicate almost always, the $22.03 \%$ sometimes and the remaining 5.08 per cent of the employees think almost never the salary meets their expectations for their performance. By another individual, the $38.23 \%$ of the opinion that the salary is attractive in relation to other institutions of higher education; $23.73 \%$ say that sometimes; a $22.03 \%$ say that almost always and the lowest percentage value with a $8.47 \%$ seen almost never your salary is attractive in relation to other institutions of higher education. Within these perspectives, the $32.20 \%$ of the respondents think always that their salary allows them to save to cover possible contingencies, while the $25.42 \%$ expressed almost never, a $18.64 \%$ of them argue that some, $13.56 \%$ think almost always and contrary to the $10.17 \%$ said that he never the salary range allows you to save to cover possible contingencies.

For the indicator interpersonal relations, the $83.05 \%$ of respondents always keeps a harmony in your relationship work despite the fact that it was reciprocal; $11.86 \%$ say almost always and the remaining 5.08\% sometimes maintains a harmony in your relationship work despite the fact that it was reciprocal. In relation to the opinion of the respondents, where the data are reflected in Table 3 the $88.14 \%$ of the view is always related with your work group to achieve together the institutional objectives, the $8.47 \%$ says almost always and $1.69 \%$, respectively indicate that some times and almost never is associated with your work group to achieve together the institutional objectives. However, the $79.66 \%$ of the employees in the administrative career is of the opinion that always communicates with your work group to plan the activities to be carried out to achieve institutional goals, the $16.95 \%$ reveal that almost always, the remaining $3.39 \%$ of them manifest sometimes carries out such communication. Within this context, in relation to the policies of the company, the $59.32 \%$ expressed that always sets the mapping of the training according to institutional policies; $25.42 \%$ manifest almost always and $15.25 \%$ stated that the company establishes the allocation of training according to institutional policies.

Then, the $54.24 \%$ are informed whenever their work taking into account the university policies, $27.12 \%$ believe that almost always; while a $16.95 \%$ of them is sometimes performed the aforementioned information. The $44.07 \%$ of the administrative career employees believe that sometimes supports the management of human talent in policies to meet the needs; $27.12 \%$ say that almost always, a $22.03 \%$ believe that always, $5.08 \%$ say that almost never and the remaining $1.69 \%$ believes that never supported the policy management to meet the needs of the human talent. In general, the results percentage of what 4.8 emphasize that the average stand out with very high presence of interpersonal relations in the universities and dimension with 4 indicating high presence. According to the results obtained it is described that the staff satisfaction is an attitude that individuals maintain with regard to their job functions ${ }^{1}$. Therefore, the dimension that aimed to study elements or indicators associated to the perception of the person on the opportunities and development in the organization, system of awards, achievements, job characteristics, mechanisms for monitoring, system or policies of salaries and wages.

At the prompt recognition, respondents, reveal that always recognized the performance of their work, receiving it in writing in response to performance achieved with greater than desired, but also shows dissatisfaction with the immediate boss when others give recognition where he participated. The recognition, as a tool associated with the personal needs such as the ego or self-esteem that every individual internalized in the work area, which are a reward for achieving stand out in a social group, in addition to the self-fulfilment and self-respect; standing out in one way or another before the other members of the organization $\frac{8,22}{}$. In relation to the indicator achievement, respondents are of the opinion that the head sometimes 
feeds on indicators achieved in their performance; receiving feedback, which encourages them to improve the continuous work to achieve the excellence of the unit, and if necessary apply corrective actions. The achievement is associated with the desire to feel a person to achieve clear objectives, self-determined and moderately complex, with feedback, based on the achievement of the objectives self-determined ${ }^{1}$.

In the characteristic of the work, the opinion of the respondents is that they always assigned work even if it is not what you expect to do; expressing his satisfaction by developing their immediate boss the job, but as rejecting the development of a job when you do not know how to construct it. This position shows that the characteristics of the work, is referred to the satisfaction of the employee in relation to the nature of the work ${ }^{1}$. In the Indicator Monitoring in the workplace respondents show that the immediate boss always encourages the management of its work where it was never establishes controls to address the immediate boss in case of doubts in the labor management, however, monitors the performance of its activities to evaluate the implementation of the activities assigned. The role of the supervisor in the institution is of vital importance, where everything that is done depends mainly on the, to be responsible for the unit, therefore, the supervisor serves as a link or link and influences their staff encouraging, promoting good relations and to serve as a paradigm to all employees of the University of $\mathrm{La}$ Guajira ${ }^{9}$.

In relation to the salaries and wages, respondents stressed that the salary expectations for their performance; being attractive in relation to other institutions of higher education allowing them to save to cover possible contingencies. The previous, to demonstrate that the salary is a motivator, governs the life pattern of each individual in the social context, in function of their work ${ }^{10}$. In addition, the structure of the salary should be equitable and fair elections in accordance with the salaries of the people in relation to the work of the Organization and the same jobs for other companies operating in the labor market. Thus, the wage is the amount of money that agreed in the contract of employment and pays ordinarily the worker ${ }^{11}$. The interpersonal relations, respondents always maintain a harmony at work despite the fact that there is reciprocal; as it relates to its working group to achieve institutional goals, leading to a Communication to plan activities. Are the interactions between co-workers or individuals who share in the same organization $\underline{13}$ ?
In relation to the policies of the company, respondents expressed that the object of study assignment training according to institutional policies; in addition to inform labor work taking into account the university policies; to support the management of human talent and thus meet the needs. Intentional Behaviors designed to increase or protect the influence and personal interests of an individual, in this case when the institution considers its staff, taking into account how policy training and both personal and professional growth of its employees to gain the knowledge and skills, thus developing their attitudes for the benefit of their work ${ }^{13}$.

\section{Conclusions}

In virtue of the results obtained in the investigation it is necessary to refer those who by way of trial allowed knowing about the situation under study. In this way, here are the general perceived of the opinion of the respondents, according to the research objective raised, analysis of the factors extrinsic job satisfaction of the administrative career employees of the University of La Guajira, in this particular job characteristics shows that the employees surveyed admitted to make the performance of the work, even if it is not what you expected to do; and later show their satisfaction with the immediate boss, who encourages you to obtain a work of excellence; but also the collaborators revealed to refuse an assignment on the work that he does not know how to develop. On the other hand, noted the respondents that are not established controls to address the immediate boss, but if the indicators for monitoring performance and evaluating the performance of assignments as an employee, which is reflected in the wage compensation that meets your expectations being attractive in comparison with other university institutions. Within this context, for interpersonal relations, there is harmony in the workplace, leading to work together to get the institutional objectives and plan the activities to be carried out; in addition to explaining institutional policies to assign the training, in order to find the satisfaction of professional and institutional needs.

\section{References}

1. Duran M. Bienestarpsicologico: el estres y la calidad de vidaen el contextolaboral. Revistanacional de administracion. 2010; 1(1):71-84. 
2. Nunez M, Salom J, Rosales V, Paz A. Responsabilidad Social Universitaria: enfoque de gestioneticacompartida. Opcion. 2012; 28(69):579-94.

3. Vergara C. Satisfaccionlaboral y compromisoorganizacionalenempleados de una universidadprivada de Lima. Revista Científica de Ciencias de la Salud. 2013; 6(1):32-42.

4. Rodriguez D, Nu-ez L, Caceres A. Estudiocomparativo de la satisfaccionlaboraluniversitariaen el nucleo de Anzoategui de la Universidad de Oriente. Investigacion y Postgrado. 2010; 25(1):63-80.

5. Robbins S. Comportamientoorganizacional. 13th Edition. Mexico: Editorial Pearson. 2013.

6. Chiang VM, Salazar BC, Rodrigo M, Jose M, Nu-ez PA. Climaorganizacional y satisfaccionlaboral: Una comparacion entre hospitalespublicos de alta y bajacomplejidad. Saludde los Trabajadores. 2011; 19(1):05-16.

7. Gibson J, Ivancevich J, Donnelly J, Konopaske R. Organizaciones: comportamiento, estructura y procesos. Macgraw Hill Interamericana Editores. 2011.

8. Bernal C. Metodologia de la Investigacion para la Administracion y Economia. Colombia. Santa Fe de Bogota: Pearson Educacion de Colombia. 2000; 6(9):111-2.

9. Naranjo R. El proceso de seleccion y contratacion del personal en las medianasempresas de la ciudad de Barranquilla (Colombia). Pensamiento \& Gestion. 2012; 32:83-114.

10. Chiavento I. Administración de recursoshumanos: El capital humano de las organizaciones/por IdalbertoChiavenato. 9th Edition. Mwxico: Mc Graw-Hill. 2011; p. 1-421.

11. Arias B. El concepto de calidad de vidaen las teorias del desarrollo. CriterioJurídicoGarantista. 2013; 5(8):136-49.

12. Chavarro J. Principiosgenerales, de la obraCodigoSustantivo y Procesal del Trabajo. 2010.
13. Jaramillo I. Principiosconstitucionales y legales del derecho del trabajocolombiano. Primera ed. Bogota: Universidad del Rosario. 2010; p. 1-14.

14. Lozada J. Investigacionaplicada: Definicion, propiedadintelectual e industria. Cienci America: Revista de divulgacioncientifica de la Universidad Tecnologica Indoamerica. 2014; 3(1):47-50.

15. Hernandez SR, Fernandez CC, Baptista LP. Metodologia de la investigacion. 6th Edition. Mc Graw Hill, Mexico. 2014.

16. Binda N, Balbastre-Benavent $\mathrm{F}$. Investigacioncuantitativa e investigacioncualitativa: buscando las ventajas de las diferentesmetodologias de investigacion. Revista de Cienciaseconomicas. 2014; 31(2):179-87.

17. Tamayo-Tamayo M. Metodologia formal de la investigacion. 4th Edition. Mexico: Editorial Limusa. 2009.

18. Mendez C. Metodologia: dise-o y desarrollo del proceso de investigacion con enfasisencienciasempresariales. 4th Edition. Mexico: Editorial Limusa. 2009.

19. Rojas V. Metodología de la Investigacion. Dise-o y ejecucion. Primera Edicion. Bogota, Colombia, mayo de. 2011; p. 1-158.

20. Dominguez-Lara S. Una modificacion del coeficiente alfa de Cronbach por errorescorrelacionados. Revistamedica de Chile. 2017; 145(2):270-1. Crossref. PMid:28453597.

21. Mastillo M, Torregoza E. Cultura de la investigacion para los estudiosurbanos, politicos einternacionales. Bogota: Universidad del Rosario. 2013; p. 1-370.

22. Baez F, Santos F. Gestion de los recursoshumanos. Estudio de caso: la comunicacionen el Hotel Rio Grande. Trabajo Final de la Carrera de Tecnico Superior enAdministracion Hotelera. Instituto superior N4044 "SOL", Seminario de Integracion. 2014. 